\title{
Protein AF-17
}

National Cancer Institute

\section{Source}

National Cancer Institute. Protein AF-17. NCI Thesaurus. Code C33947.

Protein AF-17 (1093 aa, 112 kDa) is encoded by the human MLLT6 gene. This protein may play a role in gene transcription. 